\title{
Potassium, calcium and copper phosphite to control peach rust and brown rot
}

\author{
Fosfito de potasio, calcio y cobre para controlar la roya \\ y la podredumbre del durazno
}

\author{
Ligia S. Kowata ${ }^{1}$, Giselda Alves ${ }^{* 1}$, Luciene M. Moreira ${ }^{2}$, Louise L. May-De Mio ${ }^{1}$
}

\begin{abstract}
The phosphites have been recommended as plant protectors and inducers of host resistance against diseases. Three phosphite formulations (copper, potassium and calcium) were evaluated to control peach rust (Tranzschelia discolor) and brown rot (Monilinia fructicola), in an orchard with two cultivars: 'Chimarrita' and 'BR-1'. The phosphite treatments were applied out every 30 days from September to December. The incidence and severity of leaf rust were evaluated from November to January. The fruits were harvest and assessed to brown rot incidence after three and five days. The copper phosphite reduced the rust severity in $34.8 \%$ for 'Chimarrita'. No phosphite formulation was efficient to control brown rot in the condition of the experiment. The cultivar 'Chimarrita' was more susceptible than 'BR1' in the evaluated diseases.
\end{abstract}

Key words: induced resistance, Monilinia fructicola, phosphorous acid, Tranzschelia discolor.

\section{RESUMEN}

Los fosfitos vienen siendo recomendados como protectores de plantas y como inductores de resistencia contra enfermedades. Fueron evaluadas tres formulaciones de fosfito (cobre, potasio y calcio) para el control de la roya del durazno (Tranzschelia discolor) y de la podredumbre parda (Monilinia fructicola) en un huerto con dos cultivares: 'Chimarrita' $y$ 'BR-1'. Los tratamientos con fosfitos fueron aplicados cada 30 días entre septiembre y diciembre. Fueron evaluadas la incidencia y la severidad de las enfermedades: para la roya se realizaron evaluaciones de noviembre a enero y para la podredumbre parda los frutos fueron evaluados el tercero y el quinto día después de la cosecha. El fosfito de cobre redujo la severidad de la roya en 34\% para 'Chimarrita'. Para el control de la podredumbre parda ninguna formulación de fosfito fue eficiente en las condiciones del experimento. La cultivar 'Chimarrita' fue más susceptible a las dos enfermedades estudiadas que la cultivar 'BR-1'.

Palabras clave: resistencia inducida, Monilinia fructicola, ácido fosfórico, Tranzschelia discolor.

The public concern for long-term health and environmental impacts of pesticides have been growing considerably along the time. This way, products like the phosphates have been more studied due to compensation in nutritional shortage of the plants and induce resistance against phytopathogenic fungi (Sônego; Garrido, 2005).

The phosphites are inorganic and sterile salts originated from the phosphorous acid neutralization by a basis (Cohen; Coffey, 1986) with effect of the phosphorous acid in the induction of resistance in vegetables (Jackson et al., 2000) and may interfere in incidence and severity of plant diseases (Panicker; Gangadharan, 1999). The interaction among the systemic character, fast absorption by different parts of the plant and control efficiency should be studied according to the type of the plant and characteristics of the pathogen to be controlled (Sônego; Garrido, 2005).

The study with phosphites in the disease control started in Australia in 1983, with avocado root rot (Phytophthora cinnamoni). Further, it was tested phosphites in association with fungicide captan, and some control to brown rot in peach was achieved (Moreira; May-De Mio, 2009). However, there are few reports about its effect on the control of diseases of this crop using different sources of phosphites. Consequently, the aim of the present work is to

\footnotetext{
1 Universidade Federal do Paraná. Rua dos funcionários, 1540. Setor de Ciências Agrárias. CEP 80035-050 Curitiba/PR.

* Autora para correspondência: giseldaalves@uol.com.br

2 Universidade Católica do Paraná, Campus São José dos Pinhais/ Paraná.
}

Fecha de Recepción: 4 Junio, 2012.

Fecha de Aceptación: 10 Septiembre, 2012. 
check the efficiency of the copper, potassium and calcium phosphites in the control of the brown rot (Monilinia fructicola (Wint) Honey) and the peach rust in leaves (Tranzschelia discolor (Fuckel) Tranzschel \& Litv) in the field.

The experiment was installed at experimental orchard located in Curitiba Municipality (Paraná State, Brazil) and was performed in two 4-year-old varieties (Chimarrita and BR1), placed at $0.8 \mathrm{~m}$ between plants and four meters interlines. The study was carried out from September 2006 to January 2007; the experimental design was randomized blocks with four treatments and six repetitions. The treatments and dosage used were: copper phosphite (Fitofós Cu. Agro Comercial Wiser Ltda, Diadema, SP, Brasil)-160 mL 100L-1, potassium phosphite (Fitofós K, Agro Comercial Wiser Ltda, Diadema, SP, Brasil)-100 mL 100L ${ }^{-1}$, calcium phosphite (Fitofós Ca, Agro Comercial Wiser Ltda, Diadema, SP, Brasil)-300 mL 100L $\mathrm{L}^{-1}$ and control. The applications were performed on the following dates: September, 27; October, 23; November, 17 and December, 6. At the application moment each plant was isolated by a barrier made of two wood stalks linked by resistant plastic for no interference in the treatments. The treatment was applied using plants were pulverized with a motorized backpack sprayer with a conic nozzle (capacity of 25 liters); the application volume used was $10 \mathrm{~L}$ per treatment, corresponding to $0.8 \mathrm{~L}$ per plant. In the first copper phosphite application was observed phytotoxicity in the leaves. Therefore, the dosage of this treatment was reduced to $80 \mathrm{~mL} 100 \mathrm{~L}^{-1}$.
The rust evaluations were carried out on five dates: November, 28; December, 08 and 19; January, 26 and 30 ('Chimarrita' and 'BR1', respectively). For this evaluation two branches of the year were assigned per each plant, located in opposite faces of the trees and turned to row. The incidence percentage was calculated based on the relation between the number of leaves with symptoms of the disease and the total number of leaves of the assigned branch. Rust severity assessments were made using as reference for visual estimation of the injured area diagrammatic scale for rust peach tree with five levels: 0, 0.8, 2.4, 4.5 and $13.7 \%$ (Martins, 1994-modified).The average severity per tree in the ratio of branches of each repetition was calculated.

The brown rot rate was determined on the third and fifth days after the harvest, in a sample of 30 fruits per plant (180 fruits per treatment), placed on shelves in the room, carried out under environmental conditions $\left(25^{\circ} \mathrm{C}\right.$ approximately) and continuous illumination.

The data obtained from the incidence and severity of the peach rust was the area under the disease progress curve (AUDPC), according Shaner and Finney (1977). ANOVA was the method used for data analysis and the averages were compared using Duncan test at 5\% significance. The program used for the statistical analysis was SASM- Agri version 8.0 (Canteri et al., 2001).

The AUDPC of the incidence and the severity of peach rust was lower in 'BR1', differing from 'Chimarrita' (Table 1). Some factors that may contribute to this difference are: different levels of

Table 1. Area under the disease progress curve (AUDPC) of incidence and severity of rust for different treatments applied in peach orchards with 'BR1' and 'Chimarrita' cultivars. Curitiba/ Paraná, Brazil.

\begin{tabular}{|c|c|c|c|c|}
\hline \multirow{3}{*}{ Treatment } & \multicolumn{4}{|c|}{ AUDPD } \\
\hline & \multicolumn{2}{|c|}{ Incidence } & \multicolumn{2}{|c|}{ Severity } \\
\hline & BR1 & Chimarrita & $\mathrm{BR} 1$ & Chimarrita \\
\hline Control & $2,404.15 \mathrm{a}$ & $2,732.80 \mathrm{a}$ & $6.72 \mathrm{a}$ & $18.67 \mathrm{a}$ \\
\hline Calcium phosphite & $2,381.30 \mathrm{a}$ & $2,529.24 \mathrm{a}$ & $7.22 \mathrm{a}$ & $13.83 \mathrm{a}$ \\
\hline Potassium phosphite & $2,446.85 \mathrm{a}$ & $2,592.77 \mathrm{a}$ & $8.76 \mathrm{a}$ & $13.05 \mathrm{ab}$ \\
\hline Copper phosphite & $2,386.74 \mathrm{a}$ & $2,529.09 \mathrm{a}$ & $8.54 \mathrm{a}$ & $12.18 \mathrm{~b}$ \\
\hline Means & $2,404.76 \mathrm{~B}$ & $2,595.97 \mathrm{~A}$ & $7.81 \mathrm{~B}$ & $14.43 \mathrm{~A}$ \\
\hline \multirow{2}{*}{ Coefficient of variation $(\%)$} & $6.31^{x}$ & $9.27^{\mathrm{x}}$ & $23.93^{x}$ & $30.71^{x}$ \\
\hline & \multicolumn{2}{|c|}{$8.36^{\mathrm{y}}$} & \multicolumn{2}{|c|}{$36.11^{\mathrm{y}}$} \\
\hline
\end{tabular}

Evaluation dates: 28 November, 08 and 19 December and 26 January (Chimarrita) and 30 January (BR1). Means followed by significantly different letters differ according to Duncan test $(\mathrm{P}<0.05)$. Small letters compared treatments $\left({ }^{\mathrm{x}}\right)$ and capital letters for cultivars $\left(^{\mathrm{y}}\right)$. 
susceptibility among the cultivars and the early leaf defoliation in 'Chimarrita' when compared to 'BR1' (late cultivar). High temperatures and precipitation were observed in the region where the experiment was installed. The accumulated precipitation in January is $210 \mathrm{~mm}$, with temperatures varying from $15-18^{\circ} \mathrm{C}$ (low temperature) to $25-27^{\circ} \mathrm{C}$ (high temperatures) during the evaluation period. This weather conditions were favorable for the disease epidemic according to Sutton (1988). Alves et al. (2008) also observed that 'Chimarrita' in the same region of this study was susceptible to rust under high temperatures and precipitation, causing severe defoliation and damage. Studies carried out by Martins (1994) in 'Aurora II' and 'Flor da Prince' peach orchards in Paranapanema, SP, showed that the ideal scenario for the development of the disease would be the alternation of day/night temperatures, close to $23 / 18^{\circ} \mathrm{C}$. Comparing cultivars, Citadin et al. (2010) showed that 'Chimarrita' is a high susceptible cultivar.

Our results showed that the treatments used in the cultivars 'Chimarrita' and 'BR1' did not present any statistical difference in the rust incidence, as well as, in the severity in the cultivar 'BR1'. However, in 'Chimarrita' cultivar, the copper phosphite treatment decreased the disease severity, differing from control (Table 1).

To brown rot (Table 2), no treatment was efficient to control the disease expressed during the postharvest. However, on the fifth day of evaluation, the potassium phosphite differed from calcium phosphite but not with the control. In field, in experiments with brown rot, usually, the coefficient of variation is very high, probably this can be partially explained by the inoculums distribution on the tree (Keske et al, 2010). To confirm this data should be recommended for the next experiments to assess a large number of fruit and, also separate the results of brown rot from latent infection from those on the orchard during the harvest. In experiment carried out with phosphite for the control of brown rot, Moreira and May De-Mio (2009) also used a sequence of applications with $\mathrm{CaB}$ and $\mathrm{K}$ phosphites and captan between the blooming and the harvest and got $80 \%$ of control of brown rot of peach in the harvest.

When both cultivars were compared, a higher incidence of brown rot was observed in 'Chimarrita' on both evaluation dates, with this cultivar showing a higher susceptibility to M. fructicola (Table 2). The increment in the incidence of the brown rot between the third and the fifth days of evaluation of the cultivar 'Chimarrita' may be attributed to the outbreak of fruit fly (Anastrepha fraterculus) occurred in the orchard during the harvest. Once the damage caused by the insects was homogenous in all treatments, the sample was considered adequate for the analysis.

Copper phosphite treatment reduced the rust severity in the peach tree of cultivar 'Chimarrita' by $34.8 \%$. None phosphite was efficient to control Brown rot. The cultivar 'Chimarrita' was more susceptible than 'BR1' to brown rot and peach rust.

Table 2. Brown rot (M. fructicola) incidence (\%) in peaches under different treatments. Curitiba Municipality, Paraná state, Brazil.

\begin{tabular}{|c|c|c|c|c|}
\hline \multirow{4}{*}{ Treatments } & \multicolumn{4}{|c|}{ Brown rot in fruits after harvest $(\%)$} \\
\hline & \multicolumn{2}{|c|}{ Chimarrita } & \multicolumn{2}{|c|}{ BR1 } \\
\hline & \multicolumn{4}{|c|}{ Days after the harvest } \\
\hline & 3 & 5 & 3 & 5 \\
\hline Control & $13.22 \mathrm{a}$ & $78.33 \mathrm{ab}$ & $8.65 \mathrm{a}$ & $14.29 \mathrm{a}$ \\
\hline Calcium phosphite & $12.13 \mathrm{a}$ & $85.55 \mathrm{a}$ & $11.51 \mathrm{a}$ & $17.87 \mathrm{a}$ \\
\hline Potassium phosphite & $7.97 \mathrm{a}$ & $66.59 \mathrm{~b}$ & $14.65 \mathrm{a}$ & $7.97 \mathrm{a}$ \\
\hline Copper phosphite & $5.64 \mathrm{a}$ & $72.02 \mathrm{ab}$ & $8.06 \mathrm{a}$ & $7.42 \mathrm{a}$ \\
\hline Means & 9.74 & $75.62 \mathrm{~A}$ & 10.72 & $11.89 \mathrm{~B}$ \\
\hline Coefficient of variation $(\%)^{\mathrm{w}}$ & 75.54 & $13.21^{x}$ & 67.2 & $56.92^{x}$ \\
\hline
\end{tabular}

Fruits picked on the dates 05 and 07 December for 'BR1' and 09 and 14 November for 'Chimarrita'. Means followed by significantly different letters differ according to Duncan test $(\mathrm{P}<0.05)$. Small letters compared treatments $\left({ }^{\mathrm{x}}\right)$ and capital letters for cultivars at 5 days after harvest $\left({ }^{\mathrm{y}}\right)$. ${ }^{\mathrm{w}}$ Data transformed by arc sen $(\mathrm{x}) / 100$. 


\section{References Cited}

Alves, G.; May-De Mio, L.L.; Zanette, F.; Oliveira, M.C. 2008 Ferrugem do pessegueiro e seu efeito na desfolha e na concentração de carboidratos em ramos e gemas. Tropical Plant Pathology. Brasília, v. 5, n. 33, pp. 347-353.

Canteri, M.G.; Althaus, R.A.; Virgens Filho, J.S.; Giglioti,

E.A.; Godoy, C.V.

2001 SASM-Agri: Sistema para análise e separação de médias em experimentos agrícolas pelos métodos Scott-Knott, Tukey e Duncan. Revista Brasileira de Agrocomputação. Ponta Grossa, v. 1, n. 2, pp. 18-24, 2001.

Citadin, I.; Mazaro, S.M.; Danner, M.A.; Raseira, M.C.B.; Malagi, G.

2010 Variability in leaf rust susceptibility among peach cultivars. Revista Ceres. Viçosa, v. 57, n. 2, pp. 185-193, 2010.

Cohen, M.D.; Coffey, M.D.

1986 Systemic fungicides and the control of oomycetes. Annual Review of Phytopathology. St Paul, 24, pp. 311-338, 1986.

Jackson, T.J.; Burgess, T.; Colquhoun, I.

2000 Action of the fungicide phosphite on Eucaliptus marginata inoculated with Phytophthora cinnamoni. Plant Pathology. Oxford, v. 49, pp. 147-154.

Keske, C.; Amorim, L.; Biasi, L.A.; May-De Mio, L.L.

2010 Queima das flores e podridão parda em pessegueiro sob sistema de cultivo orgânico. Ciência Rural. Santa Maria, v. 40, n. 8, pp. 1682-1688, 2010.
Martins, M.C.

1994 Quantificação dos parâmetros monolíticos e controle químico da ferrugem do pessegueiro, Piracicaba, 1994, 68f. (Dissertação de Mestrado), ESALQ-Universidade de São Paulo, Piracicaba.

Moreira, L.M.; May-De Mio, L.L.

2009 Controle da podridão parda do pessegueiro com fungicidas e fosfitos avaliados em pré e pós-colheita. Ciência e Agrotecnologia. Lavras, v. 33, pp. 405-411.

Panicker, S.; Gangadharan, K.

1999 Controlling downy mildew of maize caused by Peronosclerospora sorghi by foliar sprays of phosphonic acid compounds. Crop Protection, Kidlington, v. 18, pp. 115-118.

Shaner, G.; Finney, R.E.

1977 The effect of nitrogen fertilization on the expression of slow-mildewing resistance in Knox wheat. Phytopathology. St Paul, v. 67, pp. 1051-1056.

Sônego, O.R; Garrido, L.R.

2005 Avaliação da eficácia de algumas marcas comerciais de fosfito de potássio e de fosfonato de potássio no controle do míldio da videira. EMBRAPA Uva e Vinho. Bento Gonçalves, Circular Técnica n. 60.

Sutton, J.C.

1988 Predictive value of weather variables in the epidemiology and management of foliar disease. Fitopatologia Brasileira. Brasília, v. 13, n. 4, pp. 305-312. 